\title{
Diel feeding periodicity, daily ration and relative food consumption in some fish populations in three reservoirs of Sri Lanka
}

\author{
Wasantha S. Weliange ${ }^{1}$, Upali S. Amarasinghe ${ }^{1, a}$, Jacques Moreau ${ }^{2}$ and Maria Concepcion Villanueva $a^{2,3}$ \\ Department of Zoology, University of Kelaniya, Kelaniya 11600, Sri Lanka \\ ${ }^{2}$ Laboratoire d'Agronomie Environnement et Ecotoxicologie, INP/ENSAT, BP 32607, Auzeville-Tolosane 31326 Castanet-Tolosan Cedex, \\ France \\ ${ }^{3}$ Laboratoire Ressources halieutiques, IFREMER, BP 32, 14520 Port-en-Bessin Huppain Cedex, France
}

Received 24 November 2005; Accepted 31 August 2006

\begin{abstract}
Twelve diel surveys were carried out in three reservoirs of Sri Lanka viz. Minneriya, Udawalawe and Victoria, to investigate diel feeding patterns, daily ration and relative food consumption in fish populations. Stomach content weights of different size classes of various fish species in the three reservoirs in 12 diel surveys were analysed using an iterative method, MAXIMS. Predominantly herbivorous or detritivorous fish species such as Amblypharyngodon melettinus and Oreochromis niloticus exhibited one peak in the diel feeding pattern. Two peak feeding periods were evident in predominantly insectivores and/or zooplanktivores (e.g., Puntius chola and Rasbora daniconius) and interestingly in macrophyte feeders (i.e., Etroplus suratensis, Puntius filamentosus and Tilapia rendalli). It might be possible that all species with two feeding peaks in diel feeding patterns rely on vision for feeding. Food consumption per biomass $(Q / B$ ratio) defined as amount of food consumed per unit weight of an age-structured population of fish was estimated on the basis of the average quantities of food consumed over a long period of time by various size classes in order to minimize the bias of estimates.
\end{abstract}

Key words: Diel feeding pattern / Feeding chronology / Freshwater fish / Trophic modelling / Cyprinidae / Cichlidae

\begin{abstract}
Résumé - Périodicité nycthémérale d'alimentation, ration journalière et consommation relative chez des poissons de trois lacs artificiels du Sri Lanka. Douze séries d'échantillonnage ont été effectuées dans trois lacs-réservoirs du Sri Lanka : Minneriya, Udawalawe et Victoria, afin d'étudier le modèle journalier d'alimentation, les rations journalières et à la consommation relative des populations de poissons. Les poids des contenus stomacaux de différentes classes de taille ont ainsi été analysés en utilisant une méthode itérative, MAXIMS. Les espèces herbivores ou détritivores telles que Amblypharyngodon melettinus et Oreochromis niloticus montrent un pic dans l'activité de nutrition. Tandis que les espèces détrivores et/ou zooplanctivores en présentent deux (ex., Puntius chola et Rasbora daniconius) de même que des espèces se nourrissant de macrophytes (ex., Etroplus suratensis, Puntius filamentosus et Tilapia rendalli). Il est possible que la vision joue un rôle chez ces espèces présentant deux pics journaliers d'alimentation. La consommation de nourriture par rapport à la biomasse (le rapport $Q / B$ ) est défini comme la quantité d'aliment consommé par unité de poids d'une population de poissons structurée en âge, sur la base de quantités moyennes de nourriture consommée sur une longue période de temps et par diverses classes de taille, afin de minimiser les biais dans les estimations.
\end{abstract}

\section{Introduction}

Quantitative studies on food consumption in fish populations are an essential step towards understanding their role in aquatic ecosystems. These studies are useful to investigate the influence of the quantity of food consumed on the fish growth (Swenson and Smith 1973; Boisclair and Leggett 1989), to analyse habitat suitability for the assemblages of fish in a

\footnotetext{
a Corresponding author: zoousa@kln.ac. $1 \mathrm{k}$
}

given habitat (Kwak et al. 1992), and to assess trophic relationships in aquatic ecosystems (Christensen and Pauly 1993; Pauly 1986). Boisclair and Marchand (1993) reviewed numerous models which have been developed to accommodate different types of feeding schedules such as relatively continuous feeding schedules of omnivores and sporadic feeding schedules of piscivores, and shapes of gastric evacuation curves (i.e., linear, exponential and logistic). Boisclair and Leggett (1988), Bromley (1994) and Héroux and Magnan (1996) have also reviewed methods and models for determination of daily food 
ration in fish. Of these, the model presented by Elliott and Persson (1978), which assumes that the daily food ration can be estimated as the sum of the quantity of food consumed over a series of regular and short time intervals of a 24-hour period, is usually considered the reference point with which the models on food consumption are compared, especially in nonpiscivorous species with exponential evacuation rates. Based on this model, Jarre et al. (1990, 1991) have designed an iterative method called MAXIMS, for estimating daily food ration and amount of food consumed per unit weight of an age-structured fish population $(Q / B)$ from the data of stomach content weight estimated at regular time intervals of a 24-hours. It is a fact that however, estimations of daily ration and $Q / B$ are two independent processes, and that the latter can be estimated from daily ration calculated independently. Richter et al. (1999) who reviewed the MAXIMS model have however proposed an improved version because, mostly for small values, gut contents are not normally distributed. Richter et al. (2004) who evaluated four food consumption models including MAXIMS, have also indicated that although there are weaknesses in mathematical terms, one of the main advantages in MAXIMS model is that the evacuation rate can be determined from field data so that it is unlikely that the model overor underestimate food consumption to a significant degree if the true nature of evacuation was found.

Food consumption of fish varies from location to location and season to season. Except for the study conducted by De Silva et al. (1996) who estimated daily food ration of some indigenous cyprinid species in two reservoirs of Sri Lanka, no information is available on the diel feeding periodicity and population food consumption rates of freshwater fish species in the country.

Fish communities in Sri Lanka reservoirs are very diverse and indigenous species (mainly cyprinids) are abundant (Schiemer and Hofer 1983; De Silva and Sirisena 1987). Despite the high abundance of these small sized indigenous species, they are not commercially exploited due to poor consumer acceptability and mesh size restrictions in the gillnet fishery imposed by inland fisheries regulations in Sri Lanka (De Silva 1988). However the indigenous fish species in reservoir ecosystems can be expected to play a significant role in trophic dynamics due to their high abundance. In the present study, we investigated diel feeding patterns, daily ration and relative food consumption of nine fish species in three reservoirs of Sri Lanka, based on 24-hour surveys. This paper forms part of a detailed study directed towards trophic evaluation of reservoir and lake ecosystems in Asia (Amarasinghe et al. 2001).

\section{Material and methods}

Studies were carried out in three reservoirs of Sri Lanka: Minneriya, Udawalawe and Victoria to investigate food consumption in indigenous as well as exotic fish species. Twelve 24-hour surveys were carried out in the three reservoirs (4 in Minneriya, 5 in Udawalawe and 3 in Victoria) to determine their diel feeding patterns and fish were mostly caught in three hourly intervals. As far as possible, attempts were made to carry out diel surveys during the periods of rising water level
(RIWL) and receding water level (REWL). Here, RIWL refers to gradual increase of water level and remaining at high water level whereas REWL refers to gradual receding of water level and remaining at low water level. Weliange and Amarasinghe (2003) have shown that during RIWL and REWL, some fish species in the three reservoirs exhibit changes in food habits due to the differences in food availability. Some morphometric and physico-chemical parameters of the three reservoirs in which diel surveys were carried out are given in Table 1.

Beach seines of three sizes $(7 \mathrm{~mm}$ stretched mesh, $2 \mathrm{~m}$ in height and $50 \mathrm{~m}$ in length; $5 \mathrm{~mm}$ stretched mesh, $1.7 \mathrm{~m}$ in height and $25 \mathrm{~m}$ in length; $1 \mathrm{~mm}$ mesh size, $1 \mathrm{~m}$ in height and $8 \mathrm{~m}$ in length) were the main sampling devices. Due to the various migration patterns between inshore and offshore areas and vertical migrations exhibited by some species in different time periods of the day, multi-mesh mono-filament gillnets (12.5, $16,20,25,33,37,50,60,76$ and $90 \mathrm{~mm}$ ) were also used to sample fish.

In order to prevent deterioration of the gut contents, gillnets were set for less than half an hour depending on the abundance of the species. Fish, which were caught in gillnets and beach seines in each time interval were preserved separately in $10 \%$ buffered formalin. Before preservation, each fish was laterally dissected near the body cavity to facilitate penetration of the preservative. Fish samples were taken to laboratory for further analysis.

In the laboratory preserved specimens were identified, sorted into species and their total length and weight were measured to the nearest $0.1 \mathrm{~cm}$ and $0.1 \mathrm{~g}$ respectively, and separated into pre-defined $3 \mathrm{~cm}$ size classes. For each species, 3-15 fish per size class were taken for the analysis. The mean length and mean weight of each size class were also estimated for each species studied.

The stomach or gut of fish in each size class was isolated. As the most remarkable feature of the digestive system of cyprinids is the lack of a true stomach (Hofer 1991), contents of the anterior one-third of the gut were considered as the recently consumed food, as performed by Hofer and Schiemer (1981) and Piet (1998). In species, which had distinct stomachs (e.g., Etroplus suratensis, Oreochromis niloticus and Tilapia rendalli), only the stomach contents were used in the analysis.

The stomachs (or guts), which were separated, were pooled for each size class separately for each time interval. The wet weight in each set of pooled stomachs/guts was measured to the nearest $0.001 \mathrm{~g}$ and stomach contents were extracted. The difference in weight between the full and empty stomach gives the wet weight of the stomach contents (Getachew 1989). Mean weight of stomach/gut contents was then estimated by dividing total stomach/gut content weight from the number of stomachs/guts.

Data on stomach/gut contents were obtained from Weliange and Amarasinghe (2003) to indicate feeding habits of different size classes of fish species studied.

The mean weights of the stomach/gut contents were analysed using "MAXIMS", the computer software package developed for estimating food consumption rates (Jarre et al. 1990, 1991). In this analysis, a constant ingestion rate was assumed. The best-fitting curve for diel-feeding pattern that corresponds 
Table 1. Some morphometric and physico-chemical parameters of the three reservoirs studied (from Silva and Gamlath 2000).

\begin{tabular}{lccc}
\hline Parameter & Minneriya & Udawalawe & Victoria \\
\hline Year of construction & $276-303$ AD & 1967 & 1986 \\
Altitude $(\mathrm{m})$ & (Renovated in 1903) & 80 & 438 \\
Catchment $\left(\mathrm{km}^{2}\right)$ & 249 & 1164 & 1891 \\
Area $\left(\mathrm{km}^{2}\right)$ & 25.5 & 34.08 & 22.7 \\
Mean depth $(\mathrm{m})$ & 5.8 & 7.9 & 30.5 \\
Temperature ${ }^{\circ} \mathrm{C}$ & $27.0-31.5$ & $27.8-29.5$ & $25.5-30.0$ \\
pH & $7.32-8.35$ & $7.33-8.58$ & $7.09-7.89$ \\
Alkalinity $\left(\mathrm{mg} \mathrm{L}^{-1}\right)$ & $56-132$ & $61-89$ & $33-52$ \\
Conductivity $\left(\mu \mathrm{S} \mathrm{cm}^{-1}\right)$ & $98-213$ & $102-134$ & $66-93$ \\
Secchi Depth $(\mathrm{cm})$ & $45-280$ & $50-205$ & $95-280$ \\
Dissolved Oxygen $\left(\mathrm{mg} \mathrm{L}^{-1}\right)$ & $6.84-8.11$ & $7.11-8.02$ & $6.31-8.78$ \\
\hline
\end{tabular}

to the minimum residual sum of squares (SSR) was used to estimate daily food ration. In the MAXIMS, as in other feeding models, the diel feeding pattern is determined on the basis that during the feeding phase, the amount of stomach contents changes as a function of unknown variables, i.e., feeding rate and evacuation rate. As the ingestion rate is known to be zero during non-feeding phase, evacuation rate can be estimated to determine the ingestion rate. As the estimate of ingestion rate is highly sensitive to evacuation rate, it is imperative that a reliable estimate of evacuation rate be obtained in the analysis. In this connection, only the fish species for which at least three data points on stomach content weights corresponding to nonfeeding period were chosen for the analysis. The rest of the samples were omitted in the analysis as they could not be used for obtaining a reliable estimate of evacuation rate. The daily ration per unit body weight was determined by dividing the daily ration from the mean weight of the size class of fish.

From the values of the daily food consumption, the annual relative food consumption per biomass $(Q / B)$ was computed according to the following formula (Pauly 1986),

$$
Q / B=\int_{t_{\min }}^{t_{\max }}\left[\left(\left(\mathrm{d} W_{t} / \mathrm{d} t\right) N_{t}\right) / K 1_{t}\right] \mathrm{d} t / \int_{t_{\min }}^{t_{\max }}\left(W_{. t} N_{t}\right) \mathrm{d} t
$$

where $\mathrm{d} W_{t} / \mathrm{d} t$ is the instantaneous weight growth rate at age $t$; $N_{t}$ is the number of fish at age $t ; W_{t}$ is the mean weight of fish at age $t$; and $t_{\min }$ and $t_{\max }$ represent respectively lower and upper limits of the age range of fish considered.

The weight-age relationship of the von Bertalanffy growth curve for weight, which is expressed by the following equation, was used to estimate $W_{t}$.

$$
W_{t}=W_{\infty}\left[1-\exp \left(K\left(t-t_{\mathrm{o}}\right)\right)\right]^{b}
$$

where $W_{\infty}$ is the asymptotic body weight; $K$ is the growth constant; $t_{\mathrm{o}}$ is the theoretical age at weight zero; and $b$ is the exponent of length-weight relationship of fish. In the above equation, $K 1_{t}$ is instantaneous gross efficiency of fish at age $t$.

$$
K 1_{t}=1-\left(W_{t} / W_{\infty}\right)^{\beta}
$$

Here $\beta$ is the coefficient relating to ratio of growth increment/food ingested to body weight which was computed from the values of the daily ration and the average individual weight for each size class (Jarre et al. 1990). Daily rations of different size classes of individual species were determined for 12 diel surveys in the three reservoirs and the mean value of $\beta$ was then computed for each species in each reservoir. Based on the mean value of $\beta$ of each species, $Q / B$ ratio was computed on an annual basis from the routine implemented in MAXIMS software (Jarre et al. 1990). The other input parameters needed to estimate $Q / B$ ratio were total mortality, lower and upper limits of body weight of fish species for $Q / B$ integration (Jarre et al. 1990, 1991). Here the lower limit of body weight was considered as $0.1 \mathrm{~g}$ for all species. Ages at length zero $\left(t_{\mathrm{o}}\right)$ for individual species were estimated from the empirical relationship derived by Pauly (1983). These input parameters were obtained from various sources (see Table 2).

In fish populations, production per biomass ration $(P / B$ ratio) is known to be equal to instantaneous mortality rate (Allen 1971). Gross efficiency $[G E=P / B \div Q / B(=P / Q)$; i.e., production/consumption] was also estimated for each species in the three reservoirs by the MAXIMS software (Jarre et al. 1990).

\section{Results}

\section{Diel feeding pattern}

The present analysis was based on six Cyprinidae and three Cichlidae, which were caught in significant numbers during the diel surveys. The major food items of different size classes of the fish species studied in the three reservoirs and their number of feeding peaks in the diel feeding patterns are given in Table 2. Fish species, which were predominantly herbivorous or detritivorous [i.e., Amblypharyngodon melettinus, Puntius chola, L. rohita (Figs. 1 and 2), O. niloticus (Fig. 4e)], exhibited one peak in diel feeding pattern. In the fish species such as $D$. malabaricus and $R$. daniconius which are predominantly insectivorous and/or zooplanktivorous two peak feeding periods were evident (e.g., Figs. 2c and 2d). Interestingly, predominately macrophyte feeders (E. suratensis, P. filamentosus and T. rendalli) also had two feeding peaks (Figs. 3 and 4 ).

\section{Fish growth and mortality parameters}

The von Bertalanffy growth parameters, regression coefficients of total length ( $T L$ in $\mathrm{cm}$ ) and body weight ( $W$ in $\mathrm{g}$ ) 
Table 2. Fish species studied, their size classes (total length) and major food items ( $>10 \%)$ consumed by different size classes of fish species in the three reservoirs. Approximate proportions (\%) of different food items are given in parentheses (Weliange and Amarasinghe 2003). Number of feeding peaks in the diel feeding patterns of individual fish species are also given here.

\begin{tabular}{|c|c|c|c|}
\hline Family/Species & Reservoir & $\begin{array}{l}\text { Size class in } \\
\mathrm{cm} \text { (No. of } \\
\text { feeding peaks) }\end{array}$ & Major food items \\
\hline \multirow{5}{*}{$\begin{array}{l}\text { Cyprinidae } \\
\text { Amblypharyngodon } \\
\text { melettinus (Valenciennes) }\end{array}$} & & & \\
\hline & \multirow[t]{2}{*}{ Minneriya } & $3-6(1)$ & Detritus (85); Phytoplankton (12) \\
\hline & & $6-9(1)$ & Detritus (76); Phytoplankton (23) \\
\hline & \multirow[t]{2}{*}{ Udawalawe } & $3-6(1)$ & Detritus (75); Phytoplankton (17) \\
\hline & & $6-9(1)$ & Detritus (86), Phytoplankton (11) \\
\hline Danio malabaricus (Jerdon) & Victoria & $6-9(2)$ & Insects (85); Zooplankton (11) \\
\hline Labeo rohita (Hamilton) & Udawalawe & $15-18(1)$ & Detritus (49); Macrophytes (43) \\
\hline Puntius chola (Hamilton) & Victoria & $9-12(1)$ & Detritus (57); Insects (17); Macrophytes (12) \\
\hline \multirow{5}{*}{$\begin{array}{l}\text { Puntius filamentosus } \\
\text { (Valenciennes) }\end{array}$} & Minneriya & $6-9(2)$ & Zooplankton (28); Insects (28); Macrophytes \\
\hline & \multirow[t]{2}{*}{ Udawalawe } & $6-9(2)$ & $\begin{array}{l}\text { Macrophytes (31); Insects (28); Detritus } \\
\text { (25); Phytoplankton (10) }\end{array}$ \\
\hline & & $9-12(2)$ & $\begin{array}{l}\text { Macrophytes (20); Insects (25); Zooplankton } \\
\text { (14); Detritus (11) }\end{array}$ \\
\hline & Victoria & $9-12(2)$ & $\begin{array}{l}\text { Macrophytes (65); Insects (16); Zooplankton } \\
\text { (11) }\end{array}$ \\
\hline & & $12-15(2)$ & Macrophytes (80) \\
\hline Rasbora daniconius (Hamilton) & Minneriya & 6-9 (2) & $\begin{array}{l}\text { Insects (63); Macrophytes (18); Zooplankton } \\
\text { (14) }\end{array}$ \\
\hline \multicolumn{4}{|r|}{ (2) } \\
\hline Etroplus suratensis (Bloch) & Udawalawe & $6-9(2)$ & $\begin{array}{l}\text { Macrophytes (65); Phytoplankton (11); } \\
\text { Insects (10); Detritus (10) }\end{array}$ \\
\hline Oreochromis niloticus (L.) & Udawalawe & $12-15(1)$ & Detritus (70); Phytoplankton (12) \\
\hline \multirow[t]{2}{*}{ Tilapia rendalli (Boulenger) } & Minneriya & $\begin{array}{l}6-9(2) \\
12-15(2)\end{array}$ & $\begin{array}{l}\text { Macrophytes (59); Detritus (29) } \\
\text { Macrphytes (94) }\end{array}$ \\
\hline & Udawalawe & $6-9(2)$ & Macrophytes (65); Detritus (18) \\
\hline
\end{tabular}
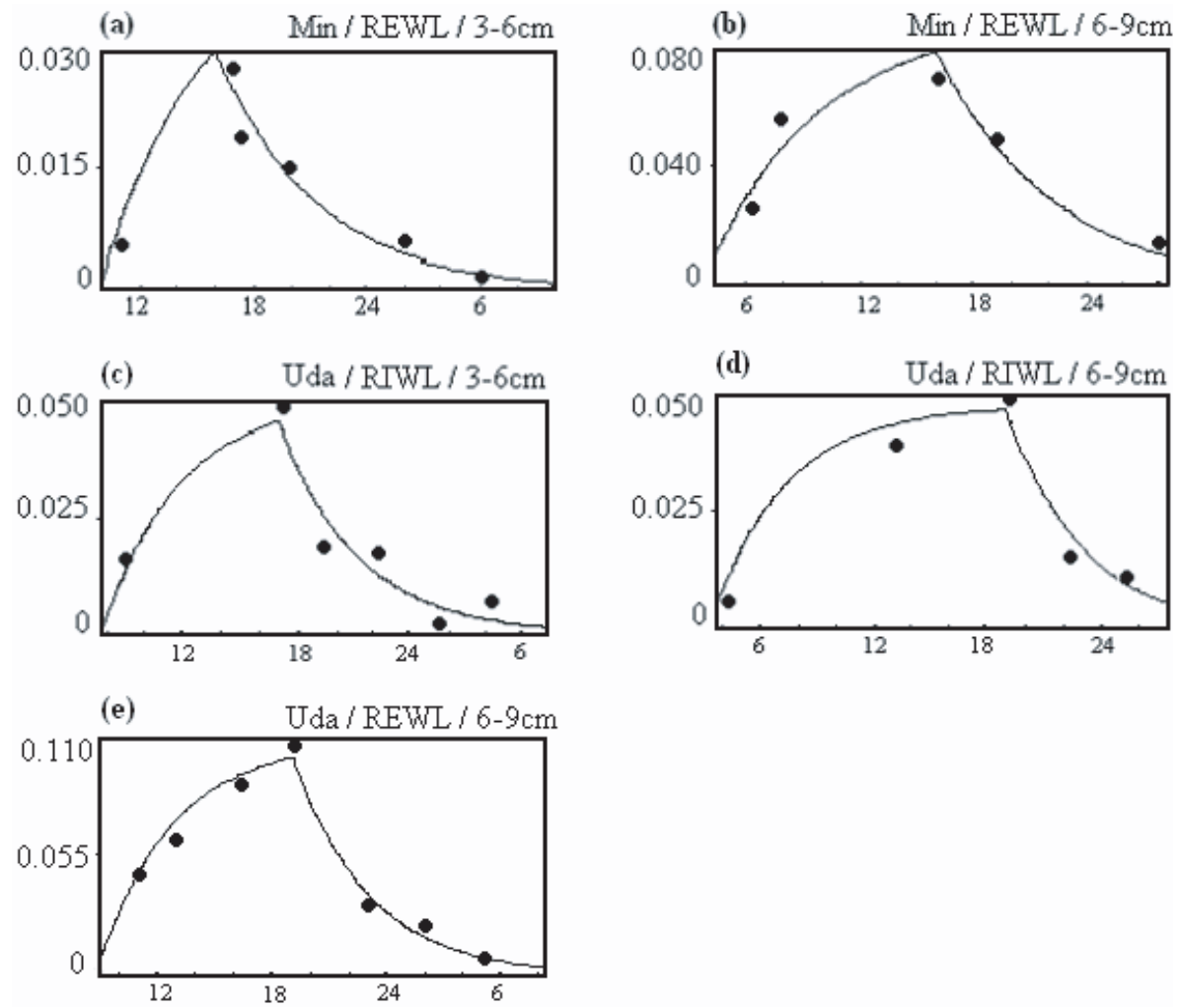

Fig. 1. Diel feeding patterns of Amblypharyngodon melettinus (Cichlidae) in three different reservoirs of Sri Lanka: Min: Minneriya, Uda: Udawalawe, Vic: Victoria. RIWL: Rising water level; REWL: Receding water level. Size classes of fish studied are also shown here. 

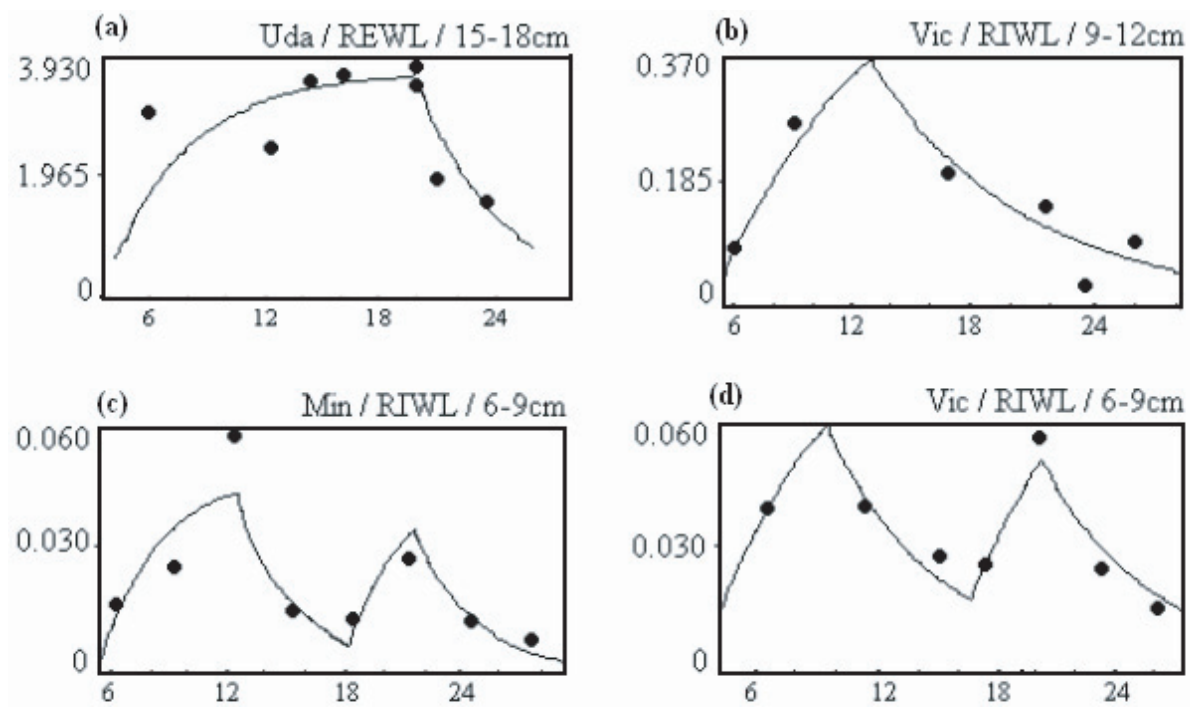

Fig. 2. Diel feeding patterns of some cyprinid species: (a) Labeo rohita, (b) Puntius chola; (c) Rasbora daniconius, (d) Danio malabaricus. See Figure 1 for other abbreviations.
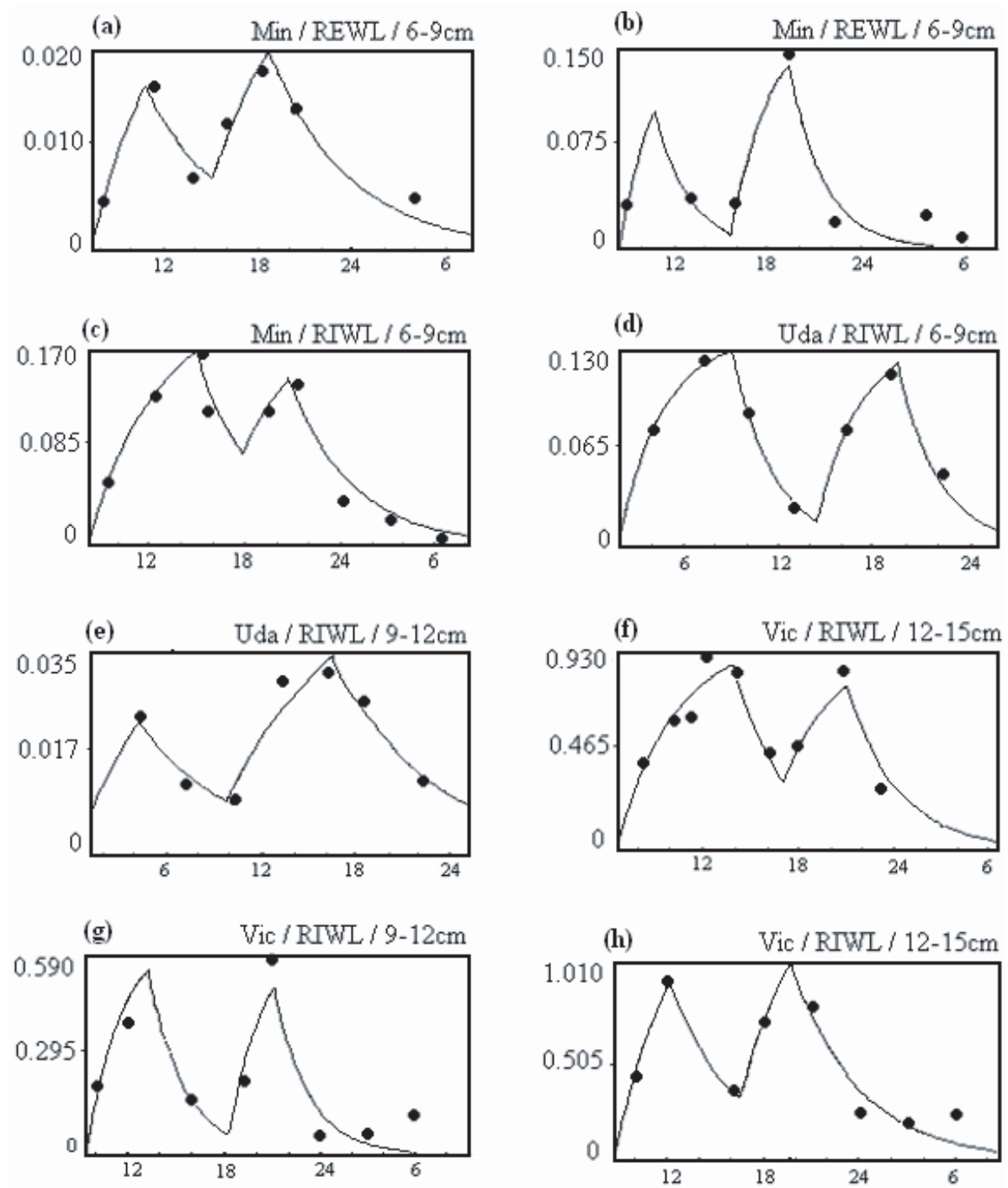

Fig. 3. Diel feeding patterns of Puntius filamentosus (Cyprinidae). See Figure 1 for other abbreviations. 

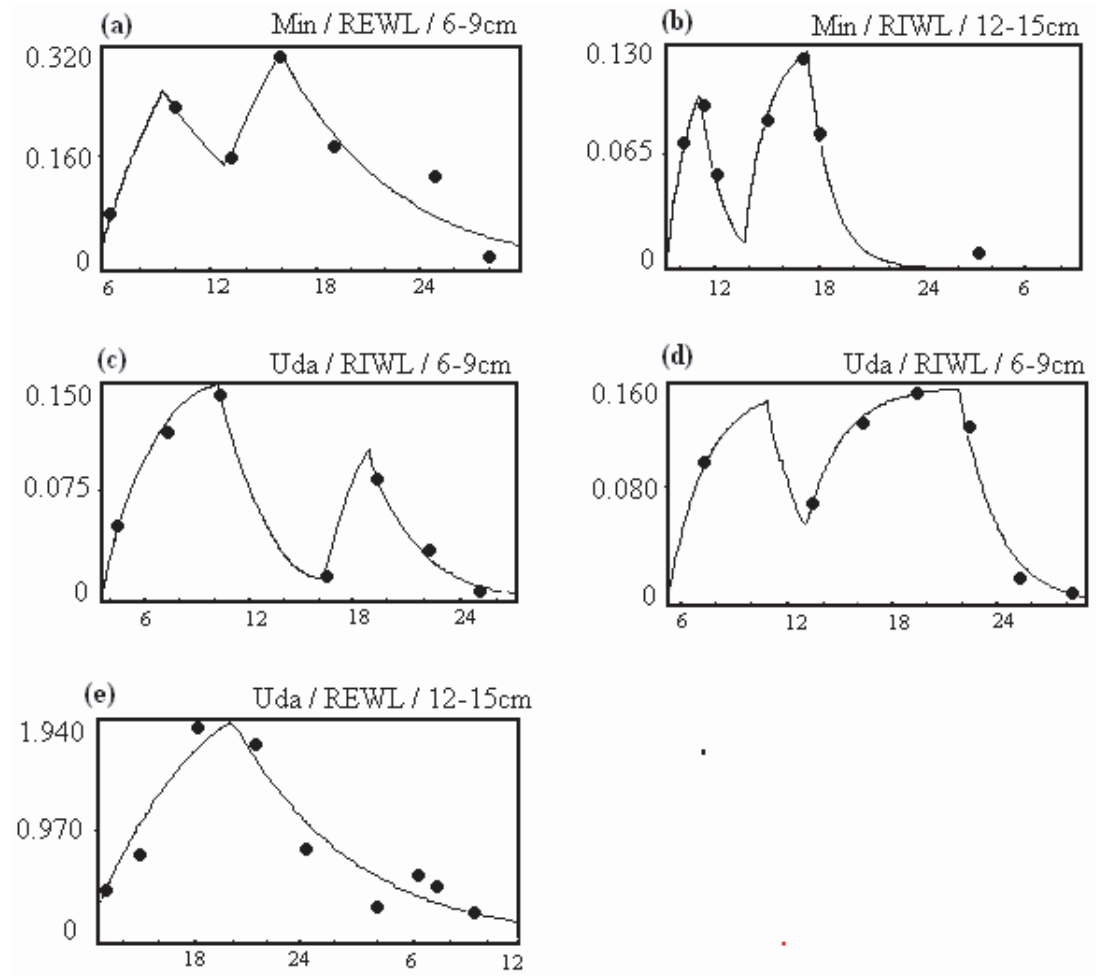

Fig. 4. Diel feeding patterns of some cichlid fish species: (a-c) Tilapia rendalli, (d) Etroplus suratensis, (e) Oreochromis niloticus. See Figure 1 for other abbreviations.

Table 3. Coefficients ( $a$ and $b$ ) of Length - Body weight ( $W=a T L^{b}$; see text) relationship of fish populations investigated, asymptotic body weight $\left(W_{\infty}\right)$ as calculated from length-body weight relationships, weight of maximum length $\left(W_{\max }\right)$, growth coefficient $(K$ per year), instantaneous total mortality rate $\left(Z\right.$ per year), theoretical age at length zero ( $t_{\mathrm{o}}$ in years). For all the size classes used in the analysis, weight at recruitment was considered $0.1 \mathrm{~g}$. Sources of data: $\uparrow$ : Moreau et al. (unpublished); *: estimated from the relationship, $L_{\infty} \approx L_{\text {max }} / 0.95$ (Pauly 1983) and length - weight relationship. $\ddagger$ : averages of values for Minneriya and Vicrotia reservoirs.

\begin{tabular}{|c|c|c|c|c|c|c|c|}
\hline Reservoir/Species & $a$ & $b$ & $W_{\infty}(\mathrm{g})$ & $W_{\max }(\mathrm{g})$ & $K$ & $Z$ & $t_{\mathrm{o}}$ \\
\hline \multicolumn{8}{|l|}{ Minneriya } \\
\hline A. melettinus $\dagger$ & 0.0052 & 3.3177 & 13.24 & 11.17 & 1.50 & 3.31 & -0.17 \\
\hline P. filamentosus $\dagger$ & 0.0121 & 3.0532 & 93.02 & 79.54 & 1.50 & 2.79 & -0.15 \\
\hline$R$. daniconius $\dagger$ & 0.0163 & 2.7320 & 18.20 & 16.53 & 0.76 & 1.88 & -0.08 \\
\hline T. rendalli $\dagger$ & 0.0131 & 2.8990 & 205.39 & 161.11 & 0.52 & 2.27 & -0.04 \\
\hline \multicolumn{8}{|l|}{ Udawalawe } \\
\hline A. melettinus $\dagger$ & 0.0122 & 2.7936 & 9.51 & 8.24 & 1.20 & 2.26 & -0.13 \\
\hline E. suratensist & 0.0390 & 2.8722 & 367.84 & 317.85 & 0.51 & 1.45 & -0.05 \\
\hline L. rohita $\dagger$ & 0.0115 & 2.9926 & 8436.81 & 7226.27 & 0.38 & 1.36 & -0.02 \\
\hline O. niloticus $\dagger$ & 0.0143 & 2.9300 & 934.66 & 540.57 & 0.49 & 2.99 & -0.04 \\
\hline P. filamentosus $\dagger$ & $0.0119 \ddagger$ & $3.0403 \ddagger$ & 56.90 & 48.68 & 1.20 & 2.46 & -0.12 \\
\hline T. rendalli $\dagger$ & 0.0155 & 3.1391 & 1089.72 & 822.52 & 0.31 & 1.13 & -0.02 \\
\hline \multicolumn{8}{|l|}{ Victoria } \\
\hline D. malabaricus $\dagger$ & 0.0162 & 2.7354 & 10.68 & 9.55 & 1.30 & 2.82 & -0.15 \\
\hline P. chola & 0.0133 & 3.0420 & $58.78 *$ & 50.29 & 1.00 & 2.80 & -0.15 \\
\hline P. filamentosus $\dagger$ & 0.0116 & 3.0274 & 88.44 & 75.12 & 1.90 & 3.15 & -0.19 \\
\hline
\end{tabular}

relationship of the form, $W=a T L^{b}$, and instantaneous total mortality coefficients of the fish species studied are given in Table 3. It must be noted that since most small-sized cyprinid species are unexploited in the three reservoirs, total mortality is essentially equal to natural mortality (see Table 3 ).

Ingestion rate, evacuation rate, number of feeding peaks and daily ration of each size class of different species in the three reservoirs are presented (Table 4). Daily ration and relative food consumption of a given fish species vary according to size of fish, from reservoir to reservoir and from season to season in a particular reservoir. However, daily ration of fish species did not show any striking pattern of differences during RIWL and REWL. Although not consistent, in general predominantly herbivorous and detritivorous fish species such as L. rohita, T. rendalli, $O$. niloticus and A. melettinus, had higher daily food ration per body weight than in carnivorous species. 
Table 4. Food consumption data of the fish species investigated. REWL - Receding water level; RIWL - Rising water level; IR - Ingestion rate $\left(\mathrm{g} \mathrm{hr}^{-1}\right)$; ER - Evacuation rate $\left(\mathrm{hr}^{-1}\right)$; DR - Daily ration $\left(\mathrm{g} \mathrm{day}^{-1}\right)$; SSR - Residual sum of squares. $\beta$ is the coefficient relating to ratio of growth increment/food ingested to body weight (Jarre et al. 1990). Mean weight, numbers of fish studied and figure numbers of the diel feeding pattern are also given here.

\begin{tabular}{|c|c|c|c|c|c|c|c|c|c|c|c|c|c|}
\hline $\begin{array}{l}\text { Species/ } \\
\text { Reservoir }\end{array}$ & $\begin{array}{l}\text { Season (Month, } \\
\text { Year) }\end{array}$ & $\begin{array}{r}\text { Size class in cm } \\
\text { (Mean Weight } \\
\text { in } \mathrm{g} \text {; No. of fish) }\end{array}$ & $\frac{\text { First fe }}{\text { Starts }}$ & ending & $\begin{array}{l}\text { Second } \\
\text { Starts }\end{array}$ & $\frac{\text { feeding }}{\text { Ends }}$ & IR & ER & DR & $\begin{array}{c}\text { DR/ body } \\
\text { weight } \\
* 100\end{array}$ & SSR & $\beta$ & Fig. No. \\
\hline \multicolumn{14}{|l|}{ A. melettinus } \\
\hline Minneriya & REWL (Feb. 1999) & $\begin{array}{r}3-6(0.8 ; 33) \\
6-9(4.2 ; 36)\end{array}$ & $\begin{array}{l}0945 \\
0930\end{array}$ & $\begin{array}{l}1615 \\
2220\end{array}$ & $\begin{array}{l}- \\
-\end{array}$ & $\begin{array}{l}- \\
-\end{array}$ & $\begin{array}{l}0.008 \\
0.016\end{array}$ & $\begin{array}{l}0.195 \\
0.165\end{array}$ & $\begin{array}{l}0.05 \\
0.17\end{array}$ & $\begin{array}{l}6.54 \\
4.09\end{array}$ & $\begin{array}{l}0.1040 \\
0.0002\end{array}$ & $\begin{array}{l}0.104 \\
0.116\end{array}$ & $\begin{array}{l}\text { 1(a) } \\
1 \text { (b) }\end{array}$ \\
\hline Udawalawe & REWL (Jul. 1999) & $\begin{array}{l}3-6(0.8 ; 40) \\
6-9(3.4 ; 29) \\
6-9(3.4 ; 40)\end{array}$ & $\begin{array}{l}0740 \\
0400 \\
0930\end{array}$ & $\begin{array}{l}1710 \\
1930 \\
1930\end{array}$ & $\begin{array}{l}- \\
- \\
-\end{array}$ & $\begin{array}{l}- \\
- \\
-\end{array}$ & $\begin{array}{l}0.012 \\
0.013 \\
0.028\end{array}$ & $\begin{array}{l}0.237 \\
0.249 \\
0.247\end{array}$ & $\begin{array}{l}0.11 \\
0.19 \\
0.28\end{array}$ & $\begin{array}{c}13.74 \\
5.65 \\
8.33\end{array}$ & $\begin{array}{l}0.0002 \\
0.0001 \\
0.0002\end{array}$ & $\begin{array}{l}0.043 \\
0.079 \\
0.053\end{array}$ & $\begin{array}{l}1(\mathrm{c}) \\
1(\mathrm{~d}) \\
1(\mathrm{e})\end{array}$ \\
\hline L. rohita & & & & & & & & & & & & & \\
\hline $\begin{array}{l}\text { Udawalawe } \\
P \text {. chola }\end{array}$ & REWL (May 2000) & $15-18(50.6 ; 38)$ & 0400 & 2000 & - & - & 0.844 & 0.233 & 13.50 & 26.69 & 3.2237 & 0.011 & 2(a) \\
\hline $\begin{array}{l}\text { Victoria } \\
R \text {. daniconius }\end{array}$ & RIWL (Jan. 1999) & $9-12(12.1 ; 32)$ & 0530 & 1310 & & & 0.073 & 0.128 & 0.55 & 4.54 & 0.0063 & 0.077 & 2(b) \\
\hline $\begin{array}{l}\text { Minneriya } \\
\text { D. malabaricus }\end{array}$ & RIWL (Dec. 1999) & $6-9(4.0 ; 45)$ & 0550 & 1240 & 1820 & 2200 & 0.015 & 0.314 & 0.15 & 3.79 & 0.0004 & 0.086 & 2(c) \\
\hline $\begin{array}{l}\text { Victoria } \\
\text { P. filamentosus }\end{array}$ & RIWL (Nov. 1999) & $6-9(4.0 ; 38)$ & 0400 & 1000 & 1640 & 2100 & 0.014 & 0.172 & 0.13 & 3.27 & 0.0001 & 0.155 & $2(d)$ \\
\hline Minneriya & REWL (Feb. 1999) & $6-9(5.7 ; 32)$ & 0700 & 1100 & 1530 & 1900 & 0.061 & 0.190 & 0.42 & 7.44 & 0.0012 & 0.103 & $3(\mathrm{a})$ \\
\hline & $\begin{array}{l}\text { REWL (Jul. 1999) } \\
\text { RIWL (Dec. 1999) }\end{array}$ & $\begin{array}{l}6-9(5.7 ; 35) \\
6-9(5.7 ; 43)\end{array}$ & $\begin{array}{l}0800 \\
0800\end{array}$ & $\begin{array}{l}1100 \\
1540\end{array}$ & $\begin{array}{l}1540 \\
1800\end{array}$ & $\begin{array}{l}1930 \\
2130\end{array}$ & $\begin{array}{l}0.074 \\
0.051\end{array}$ & $\begin{array}{l}0.432 \\
0.246\end{array}$ & $\begin{array}{l}0.44 \\
0.49\end{array}$ & $\begin{array}{l}7.71 \\
8.62\end{array}$ & $\begin{array}{l}0.0012 \\
0.0019\end{array}$ & $\begin{array}{l}0.098 \\
0.083\end{array}$ & $\begin{array}{l}3(\mathrm{~b}) \\
3(\mathrm{c})\end{array}$ \\
\hline Udawalawe & RIWL (Feb. 1999) & 6-9 $(5.2 ; 42)$ & 0200 & 0900 & 1300 & 2000 & 0.053 & 0.370 & 0.64 & 10.35 & 0.0001 & 0.042 & $3(\mathrm{~d})$ \\
\hline & RIWL (Feb. 1999) & $9-12(14.3 ; 39)$ & 0200 & 0430 & 1000 & 1700 & 0.076 & 0.158 & 0.75 & 5.06 & 0.0037 & 0.083 & $3(\mathrm{e})$ \\
\hline Victoria & RIWL (Jan. 1999) & $12-15(30.7 ; 42)$ & 0630 & 1400 & 1720 & 2130 & 0.290 & 0.300 & 3.22 & 10.50 & 0.0562 & 0.061 & $3(f)$ \\
\hline & RIWL (Jul. 1999) & $9-12(14.3 ; 43)$ & 0930 & 1330 & 1830 & 2130 & 0.301 & 0.448 & 2.01 & 14.06 & 0.0352 & 0.053 & $3(\mathrm{~g})$ \\
\hline & RIWL (Jul. 1999) & $12-15(30.7 ; 44)$ & 0710 & 1200 & 1640 & 2000 & 0.379 & 0.233 & 2.50 & 8.17 & 0.0406 & 0.079 & $3(\mathrm{~h})$ \\
\hline T. rendalli & & & & & & & & & & & & & \\
\hline Minneriya & REWL (Jul. 1999) & $6-9(4.5 ; 36)$ & 0530 & 0930 & 1300 & 1600 & 0.089 & 0.155 & 0.60 & 13.35 & 0.0045 & 0.024 & 4(a) \\
\hline & RIWL (May 2000) & $12-15(11.9 ; 40)$ & 0900 & 1100 & 1400 & 1740 & 1.029 & 0.743 & 5.66 & 22.83 & 0.0092 & 0.010 & 4(b) \\
\hline $\begin{array}{l}\text { Udawalawe } \\
\text { E. suratensis }\end{array}$ & RIWL (Feb. 1999) & 6-9 $(8.7 ; 39)$ & 0330 & 1100 & 1600 & 1900 & 0.059 & 0.361 & 0.54 & 6.22 & 0.0001 & 0.034 & 4(c) \\
\hline $\begin{array}{l}\text { Udawalawe } \\
\text { O. niloticus }\end{array}$ & RIWL (Feb. 1999) & $6-9(12.7 ; 34)$ & 0730 & 1100 & 1300 & 2200 & 0.074 & 0.457 & 1.07 & 8.41 & 0.0002 & 0.035 & 4(d) \\
\hline Udawalawe & REWL (May 2000) & $12-15(29.3 ; 38)$ & 1200 & 2000 & & & 0.352 & 0.152 & 2.73 & 9.30 & 0.2728 & 0.030 & $4(\mathrm{e})$ \\
\hline
\end{tabular}

\section{$Q / B$ ratio and gross efficiency}

$Q / B$ ratio and $G E$ of each species in the three reservoirs are presented in Table 5. Generally, $G E$ of herbivorous species (e.g., T. rendalli) is much lower than in omnivorous species such as D. malabaricus and P. chola.

\section{Discussion}

This study is based on an extensive field study of several fish species in three Sri Lankan reservoirs to quantify daily ration and $Q / B$ ratio of each species inhabiting each of the three reservoirs. The MAXIMS model for quantifying food consumption however, is explicitly based on the assumption that evacuation rate is proportional to the level of stomach fullness. As cyprinids do not have true stomachs, this assumption is expected to be violated. Hofer (1991) indicated that although lacking a stomach, many cyprinids, particularly in tropical and subtropical regions do not have significant differences from those with stomachs in the process of protein digestion. The fish stomach also plays an important role as a storage organ but in cyprinids due to the lack of stomach, this storage capacity is partly made up for by an extension of the foregut, the intestinal bulb, where most of the important digestive processes take place (Hofer 1991). As such, it can be suggested that in cyprinids, evacuation of food from the intestinal bulb is perhaps somewhat similar to the process that takes place in fish with stomach. This is evident from the diel feeding patterns of most cyprinid species in the three reservoirs (Figs. 1-3) where stomach/gut fullness has not come to a distinct plateau.

According to present analysis, daily ration of $L$. rohita is high ( $>25 \%$ of body weight) possibly due to the reason that the estimates were based on juvenile fish (mean weight $-50.7 \mathrm{~g}$ ) whose maximum weight is about $7.5 \mathrm{~kg}$.

In the model for estimating $Q / B$ ratio from daily food consumption on the basis of gross food conversion efficiency $(F C E)$, as implemented in the MAXIMS software (Jarre et al. $1991)$, the estimates are highly sensitive to the conditions under which daily ration has been determined. FCE varies with various factors such as size of fish, water temperature, food quality, etc. In most tropical fish communities, variations in 
Table 5. $Q / B$ ratio and gross efficiency of fish species studied in three reservoirs of Sri Lanka.

\begin{tabular}{llcc}
\hline Reservoir & Family/Species & $\begin{array}{r}Q / B \text { ratio } \\
\text { (annual) }\end{array}$ & $\begin{array}{c}\text { Gross } \\
\text { efficiency }\end{array}$ \\
\hline Minneriya & Cichlidae & & \\
& T. rendalli & 46.36 & 0.049 \\
& Cyprinidae & & \\
& A. melettinus & 18.70 & 0.177 \\
& P. filamentosus & 21.66 & 0.129 \\
& R. daniconius & 12.92 & 0.146 \\
Udawalawe & Cichlidae & & \\
& E. suratensis & 22.10 & 0.066 \\
& O. niloticus & 31.82 & 0.094 \\
& T. rendalli & 13.83 & 0.082 \\
& Cyprinidae & & \\
& A. melettinus & 27.38 & 0.082 \\
& L. rohita & 54.17 & 0.025 \\
Victoria & P. filamentosus & 26.23 & 0.094 \\
& Cyprinidae & & \\
& D. malabaricus & 13.60 & 0.207 \\
& P. chola & 19.43 & 0.144 \\
& P. filamentosus & 38.68 & 0.081 \\
\hline
\end{tabular}

food habits due to seasonal availability of food resources associated with seasonal flood patterns are evident especially in euryphagous fish species (Maitipe and De Silva 1985; Welcomme 2001) so that the estimates of average food consumed over a long period should be obtained on the basis of daily ration of fish species during different seasons. Weliange and Amarasinghe (2003) reported that in some fish species, feeding habits show slight variations among the three reservoirs studied as well as between RIWL and REWL in each reservoir possibly due to differences in availability of food items. However, considerable difference in daily ration of fish species during the two seasons is not evident in the present study. In the present analysis, growth parameters of most fish species in the three reservoirs were determined from the length frequency data collected during the same period that the present study was carried out (Moreau et al., unpublished). Also estimates of $Q / B$ were based on the average quantities of food consumed over a long period of time by various size classes. As such, it can be considered that the bias of the estimates of $Q / B$ that might be brought about by $\beta$ and exponent of the length-weight relationship is minimal for the fish species in the present analysis. However, for $L$. rohita in Udawalawe reservoir, estimates of $Q / B$ were based on the daily ration of juvenile fish so that there may be bias in the population food consumption estimates.

Quantitative studies on daily ration and food consumption in fish populations based on field sampling have the advantage over those based on laboratory observations because the former permits working in the environmental conditions in which the species lives. Field sampling also allows estimates of daily rations and food consumption rates based on natural diets, which are difficult to replicate in the laboratory. The iterative method, MAXIMS offers an effective means for determining daily food ration of fish populations from a 24-hour cycle of stomach/gut content weights. In the present analysis, two peak feeding periods were evident in fish species such as $D$. malabaricus and $R$. daniconius which are predominantly insectivorous and/or zooplanktivorous, and for predominantly macrophyte feeders (T. rendalli, P. filamentosus and $E$. suratensis). It may be possible that fish species, which are predominantly zooplanktivorous, insectivorous and macrophyte feeders, rely on vision for feeding.

Daily ration of a given species with varies size of fish (Pauly 1989; Palomares and Pauly 1998). As such, it is imperative to use daily ration per unit body weight for comparative analyses (Pauly 1986). The present analysis reveals that the daily ration per body weight is considerably higher in most fish species, which are predominantly herbivorous and detritivorous than in carnivorous (i.e., piscivorous and zooplanktivorous) fish species. Garcia and Duarte (2002) have observed similar results in some Caribbean fish species and shown that their seasonal foraging activity is modified as a compromise between the consumption of highly abundant plant or decaying materials and rare animal food items. The differences in the relative food consumption between the herbivorous and carnivorous fish species may be due to the differences in nutritive quality of plant food items and animal prey (Jobling 1981; De Silva 1985; García and Duarte 2002). Daily ration per body weight estimates of cyprinid species in the present study are comparable with those estimated for same species in two other Sri Lankan reservoirs (De Silva et al. 1996).

$Q / B$ ratios of constituent species in fish communities are among the parameters required in trophic interaction models (Garcia and Duarte 2002) such as ECOPATH (Christensen et al. 2000), which are useful to assess fisheries within the context of the overall ecosystem that supports them. Although food consumption rates of fish populations are difficult to estimate, the algorithms presented by Jarre et al. $(1990,1991)$ in the MAXIMS software make this task easier.

In MAXIMS, mean weight of stomach/gut content in a time trajectory is used to determine daily ration, but it is a fact that the stomach/gut content weight in a given time interval is highly variable. However especially when the stomachs/guts are small, it is difficult to determine their content weights with great precision so that as performed in the present analysis, stomach/gut contents pooled for several specimens have to be determined in order to determine the mean values. This of course prevents estimation of errors associated with stomach/gut content weight data with high variability. Although not performed in the present study, determination of wet weight of stomach contents of individual fish separately using a balance with great precision, as carried out by De Silva et al. (1996), is possible to overcome this problem. Alternatively as suggested by Boisclair and Marchand (1993), weight of the contents in the stomach and complete digestive tract can be determined for individual fish, which permits estimation of errors associated with data. Similar limitation has been indicated for the Elliott and Persson's (1978) daily ration model. However, appropriateness of this method for determining diel variations in food ingestion in herbivorous and omnivorous fish species is questionable because in such fish species, most digestion takes place in posterior part of the digestive tract. Another limitation is that the models implemented in MAXIMS software do not produce confidence intervals of estimated values of daily ration and $Q / B$ ratio. As already mentioned, for 
fish species without stomach, the assumption in the MAXIMS model that the evacuation rate is proportional to the amount of stomach fullness may be violated. Despite these limitations, the MAXIMS software provides an effective means of getting reasonable estimates of daily food ration and relative food consumption of fish populations.

Acknowledgements. This study was carried out as part of a research project funded by European Union INCO-DC Programme (Project Number: IC18-CT-0190). The authors thank two anonymous referees for their comments.

\section{References}

Allen K.R., 1971, Relation between production and biomass. J. Fish. Res. Board Can. 28, 15731581.

Amarasinghe U.S., Duncan A., Moreau J., Schiemer F., Simon D., Vijverberg J., 2001, Promotion of sustainable fisheries and aquaculture in Asian reservoirs and lakes. Hydrobiologia 458, 181190.

Boisclair D., Leggett W.C., 1988, An in situ experimental evaluation of the Elliott and Persson and the Eggers models for estimating fish daily ration. Can. J. Fish. Aquat. Sci. 45, 138-145.

Boisclair D., Leggett W.C., 1989, Among-population variability of fish growth: I. Influence of the quantity of food consumed. Can. J. Fish. Aquat. Sci. 46, 457-467.

Boisclair D., Marchand F., 1993, The guts to estimate fish daily ration. Can. J. Fish. Aquat. Sci. 50, 1969-1975.

Bromley P.J., 1994, The role of gastric evacuation experiments in quantifying the feeding rates of predatory fish. Rev. Fish Biol. Fish. 4, 36-66.

Christensen V., Pauly D. (Eds.), 1993, Trophic Models of Aquatic Ecosystems. Manila, International Centre for Living Aquatic Resources Management, ICLARM Conf. Proc. 26.

Christensen V., Walters C.J., Pauly D., 2000, Ecopath with Ecosim: a User's Guide, October 2000 Edition. Vancouver, Fisheries Centre, University of British Columbia and Penang, International Centre for Living Aquatic Resources Management.

De Silva S.S., 1985, Body condition and nutritional ecology of Oreochromis mossambicus (Pisces, Cichlidae) populations of man-made lakes in Sri Lanka. J. Fish Biol. 27, 621-633.

De Silva S.S., 1988, Reservoirs of Sri Lanka and their fisheries. FAO Fish. Tech. Pap. 298, 128.

De Silva S.S., Amarasinghe U.S., Wijegoonawardena N.D.N.S., 1996, Diel feeding patterns and daily ration of cyprinid species in the wild determined using an iterative method, MAXIMS. J. Fish Biol. 49, 1153-1162.

De Silva S.S., Sirisena H.K.G., 1987, New fish resources of reservoirs in Sri Lanka: Feasibility of introduction of a subsidiary gillnet fishery for minor cyprinids. Fish. Res. 6, 17-34.

Elliott J.M., Persson L., 1978, The estimation of daily rates of food consumption for fish. J. Animal Ecol. 47, 977-991.

García C.B., Duarte L.O., 2002, Consumption to biomass (Q/B) ratio and estimates of $\mathrm{Q} / \mathrm{B}$-predictor parameters for Carribean fishes. Naga 25, 19-31.

Getachew T., 1989, Stomach pH, feeding rhythm and ingestion rate in Oreochromis niloticus L. (Pisces: Cichlidae) in lake Awasa, Ethiopia. Hydrobiologia 174, 43-48.

Héroux D., Magnan P., 1996, In situ determination of food daily ration in fish: review and field evaluation. Environ. Biol. Fish. 46, 61-74.
Hofer R., 1991, Digestion. In: Winfield I.J., Nelson J.S. (Eds.), Cyprinid Fishes: Systematics, Biology and Exploitation , pp. 413425. Fish and Fisheries Series 3, Chapman and Hall, London.

Hofer R., Schiemer F., 1981, Proteolytic activity in the digestive tract of several species of fish with different feeding habits. Oecologia $48,342-345$.

Jarre A., Palomares M.L., Soriano M.L., Sambilay Jr. V.C., Pauly D., 1990, A user's manual for MAXIMS. A computer program for estimating the food consumption of fishes from diel stomach contents data and population parameters. Manila, International Centre for Living Aquatic Resources Management, ICLARM Software 4.

Jarre A., Palomares M.L., Soriano M.L., Sambilay Jr. V.C., Pauly D., 1991, Some new analytical and comparative methods for estimating the food consumption of fishes. ICES Mar. Sci. Symp. 193, 99-108.

Jobling M., 1981, Mathematical models of gastric emptying and the estimation of daily rates of food consumption for fish. J. Fish Biol. 19, 245-257.

Kwak T.J., Wiley M.J., Osborne L.L., Larimore R.W., 1992, Application of diel feeding chronology to habitat suitability analysis of warm-water stream fishes. Can. J. Fish. Aquat. Sci. 49, 1417-1430.

Maitipe P., De Silva S.S., 1985, Switches between zoophagy, phytophagy and detritivory of Sarotherodon mossambicus (Peters) populations in twelve man-made Sri Lankan lakes. J. Fish Biol. 26, 83-95.

Palomares M.L., Pauly D., 1998, Predicting food consumption of fish populations as functions of mortality, food type, morphometrics, temperature and salinity. J. Mar. Freshwater Res. 49, 447-453.

Pauly D., 1983, Some simple methods for the assessment of tropical fish stocks. FAO Fish. Tech. Pap. 234.

Pauly D., 1986, A simple method for estimating the food consumption of fish populations from growth data and food conversion experiments. Fish. Bull. 84, 827-840.

Pauly D., 1989, A simple index of metabolic level in fishes. Fishbyte 7, 22.

Piet G.J., 1998, Ecomorphology of a size-structured tropical freshwater fish community. Environ. Biol. Fish. 51, 67-86.

Richter H., Focken U., Beker K., 1999, A review of the fish feeding model Maxims. Ecol. Model. 120, 47-64.

Richter H., Luckstadt C., Focken U., Becker K., 2004, Some mathematical considerations in estimating daily ration in fish using food consumption models. Ecol. Model. 171, 381-393.

Schiemer F., Hofer R., 1983, A contribution to the ecology of the fish fauna of the Parakrama Samudra reservoir. In: F. Schiemer (Ed.) The Limnology of Parakrama Samudra, Sri Lanka. A case study of an ancient man-made lake in the tropics, The Hague, Dr. W. Junk Publishers, pp. 135-154.

Silva E.I.L., Gamlath G.A.R.K., 2000, Catchment characteristics and water quality of three reservoirs (Victoria, Minneriya and Udawalawe) in Sri Lanka. Sri Lanka J. Aquat. Sci. 5, 55-73.

Swenson W.A., Smith Jr. L.L., 1973, Gastric digestion, food consumption, feeding periodicity, and the conversion efficiency in walleye (Stizostedion vitreum). J. Fish. Res. Board Can. 30, 13271336.

Welcomme R.L., 2001, Inland Fisheries: Ecology and Management, Fishing News Books, Blackwell Science, Oxford.

Weliange W.S., Amarasinghe U.S., 2003, Seasonality in dietary shifts in size-structured freshwater fish assemblages in three reservoirs of Sri Lanka. Environ. Biol. Fish. 68, 269-282. 